\title{
FUTURE OF ALLOTMENT GARDENS IN THE CONTEXT OF CITY SPATIAL POLICY - A CASE STUDY OF POZNAŃ
}

\author{
Lidia Poniży, Kamila Stachura \\ ${ }^{1}$ Department of Integrated Geography, Adam Mickiewicz University in Poznan, Poland
}

Manuscript received: September 13, 2016

Revised version: February 14, 2016

Poniży L., Stachura K., 2017. Future of allotment gardens in the context of city spatial policy - A Case Study of Poznań. Quaestiones Geographicae 36(1), Bogucki Wydawnictwo Naukowe, Poznań, pp. 121-127, 1 fig, 1 table.

\begin{abstract}
AвSTRACT: Multifunctional allotment gardens are an important part of the green infrastructure of cities. In spite of this, they are given little attention in the plans and policies of cities. One of the major threats to the existence of allotment gardens within the spatial structure of cities is the pressure of investment, which results from an underestimation of the role of gardens. The task of preserving allotment gardens in the ecosystems of cities rests with the local spatial planning. Urban spatial policy towards allotment gardening is exemplified by the case study of Poznan. The bases for the analysis include the study of the conditions and directions of spatial planning, as the spatial policy document that sets forth the city and local spatial development plans, which are Acts of local laws.
\end{abstract}

KEY WORDS: Allotment gardens, green infrastructure, spatial policy, planning documents

Corresponding author: lidkap@amu.edu.pl

\section{Introduction}

The benefits of the operation of green areas in the city are widely noticeable. For city dwellers, they are areas for recreation and relaxation (Jim, Chen 2006), providing positive aesthetics and meeting social needs. The green areas are conducive to improving the quality of the natural environment of the city by reducing air pollution, as well as improving the local climate (Malinowska, Szumacher 2008, Gill et al. 2007, Tratalos et al. 2007). The regulation of surface runoff of water (Wise 2008), protection of water and soil (Pauleit, Duhme 2000), a place of refuge for many organisms and favoring the maintenance of biodiversity (Müller et al. 2010, Hostetler et al. 2011), are additional functions of green areas in cities Tyrväinen et al. (2005) indicates the diversity of the benefits provided by forests and wooded areas in cities. Sandström (2002) pays particular attention to the versatility of green areas, presenting the concept of green infrastructure, along with technical infrastructure, among others, with buildings and communication network, and postulating the 'equal approach' in the planning of cities.

Providing a large area of healthy, well-functioning system of green areas is one of the basic ways of shaping the spatial structure of cities. Allotment gardens play a significant role in this system. They are an important element of urban green infrastructure (Breuste 2010), and provide a lot of benefits to their users as well as other inhabitants of the cities (Kronenberg et al. 2013, Langemeyer et al. 2016), but above all the provisioning services, which is the food supply (as 
vegetables, fruits and herbs) distinguish them from other green areas in the city. Allotment gardens have been functioning in the structure of European cities for two hundred years now. Also in Poland, the tradition of urban allotment gardening is quite old. It began in 1897, in Grudziądz, with the establishment of the first allotment garden called "Sun Baths" (Kapiele Stoneczne).

From their inception, they have been perceived as multifunctional green areas. The new law of 13th December, 2013 regarding family allotment gardens (FAG), lists various functions of allotment gardens as:

- meeting the leisure and recreational needs of the society by facilitating the cultivation of gardens

- improvement of social conditions for members of local communities;

- helping families and individuals facing difficult situations by ensuring equal opportunities;

- integration of the extended family, bringing up children in healthy conditions and the maintenance of active and healthy lifestyle for pensioners;

- social integration for people at retirement as well as the disabled;

- restoration of degraded terrains to the community and nature;

- environmental protection and nature conservation;

- impact on the improvement of ecological conditions in municipalities;

- shaping a healthy environment for people;

- creating the conditions for providing green areas for local communities.

The legislature addresses a wide range of services provided by allotment gardens towards the improvement of the quality of life for city dwellers. Thus, qualifying them as a very important part of the green infrastructure of the city and as such should be included in the local programs and policies for the development of cities.

\section{The aim of the study}

The local government has broad powers in policy planning. The community's task includes the development of planning documents, which determine the directions of spatial development.
The most important studies at the local level include the study of the conditions and directions of spatial development $\left(\mathrm{SUiKZP}^{1}\right)$ and local plans of spatial development $\left(\mathrm{MPZP}^{2}\right)$. The provisions of these documents also apply to allotment gardens, as the objects in the spatial structure of the city, which are the subject for spatial planning. The aim of the study was to determine the approach of Poznan authorities to solving the puzzling issue of allotment gardens and their perception in the spatial structure of the city, and, on this basis, the assessment of the position of allotment gardens in the future. Hence, the above-mentioned planning documents prepared for Poznan: SUiKZP of the city of Poznan (2008), SUiKZP of the city of Poznan (2014) and the current MPZP were analyzed. The graphical documents and attachments available on the website of the Municipal Urban Planning Workshop in Poznan were used. The location of allotment gardens and their coverage through the MPZP was determined based on data gathered from the Municipal Map of Spatial Information System ZGiKM (Management Board of Geodesy and City Cadaster) GEOPOZ. Data on the allotment gardens were verified based on the information obtained at the District Board of the Polish Allotment Gardeners Association in Poznan.

Currently in Poznan, there are 94 allotment gardens, while the creation of the next two is being planned. In total, 96 allotment gardens were taken into consideration in this research.

\section{Allotment gardens as a subject of spatial planning of the city}

The position of allotment gardens in urban areas is determined by legal regulations, local spatial and environmental policy as well as local laws. Poland is one of the few European countries where the issue of allotment gardens is regulated by law (Drilling et al. 2016). This has allowed the gardens to survive turbulent times of political transformation and protected them from the pressure of investors. At the same time,

SUiKZP studium uwarunkowań i kierunków zagospodarowania przestrzennego

2 MPZP - miejscowy plan zagospodarowania przestrzennego 
since the 90s of the last century, the municipality has shown significant expertise in creating spatial policy and local law-making process. Consequently, the role and place of allotment gardens in the spatial structure of the city, largely depends on the decision of the local government.

The basis for spatial planning at the local level is the study of conditions and directions of spatial development as well as local plans of spatial development. The first document is drawn up for the whole area of the municipality. It is determined largely on the allocation of land and future forms of development. It is the internal management act and is not a local law, but, rather, the records contained therein are binding on the process of the preparation of local plans. MPZP is a local law and must respect the provisions of SUiKZP.

In both documents, the allotment gardens are indicated by "green allotments", which suggests that they are perceived as green areas. Such a signature for MPZP results from the provisions of the Regulation of the Minister of Infrastructure of 26 August 2003, on the required scope of the project of the local plan of spatial development. According to which allotment gardens are placed under the "green and water areas" not in the "agricultural areas", although allotment gardens are classified as agricultural land according to the Act of 3 February 1995, regarding the protection of agricultural and forest land. On the other hand, the Family Allotment Gardens Act, (previously of 8 July 2005 and presently of 13 December 2013) designate these gardens as a green areas.

The lack of consistency in the recognition of allotment gardens in the legal act causes difficulties in formulating entries in planning documents. Pawlak (2013) points out this problem, presenting the legal and planning position of Warsaw allotment gardens.

\section{Allotment gardens in the context of the green areas of Poznan}

Most of the valuable natural areas of the city are included in the wedge-ring system of green areas. This system is a traditional, geographically and historically conditioned, urban planning scheme, which is present in all planning documents prepared for the area of the city since the period between the two World Wars. The main wedges of green are the areas which extend from the suburban areas to the city center along the depressions of Warta river valley and its tributaries - Cybina and Bogdanka. They are complemented by the ecological corridors of Junikowski Stream, as well as Głuszynka, Michałówka and Różany Potok. The concentric rings, however, are formed by green areas created by the ramparts of the city and the Prussian fortifications that are supposed to be a form of connectors between the wedges. However, the development of a compact downtown built-up area resulted in a break in continuity of the rings of green. As a result, it is currently very difficult to find the remains of these continuous spatial structures on the city plan.

Apart from the afore-mentioned wedge-ring system, Poznan green infrastructure is also created by the green areas scattered among building developments of varying intensity.

One of the elements that make up the green infrastructure of the city, both within the structural wedges of green, as well as green enclaves within built-up areas, is allotment gardens. Those situated within the administrative boundaries of the city cover just over 800 hectares, which represents approx. $3.1 \%$ of the Poznan area. It is a large area, not much smaller than the urban green space of both public and housing estates (including walking and recreational parks, lawns and green neighborhood) that covers an area of 877,1 ha, which is $3.3 \%$ of the city area (CSO 2009). The first sets of allotment gardens were created in the early twentieth century. Some of them have run continuously until today. A section of the gardens was closed down; some of them have lost their allotment character and, nowadays, only serve the function of residential areas. However, allotment gardens remain an important element of the urban landscape. There are currently more than 90 such gardens in Poznan ${ }^{3}$ comprising of about 20000 plots. If we assume that one plot is used by approx. 3-4 people, we can conclude that around $60000-80000$ (11-15\% ) city dwellers use this type of green areas.

\footnotetext{
At the end of 2013, before the new Law on allotment gardens came into power, in Poznan Polish Allotment Gardeners Association managed 92 allotment gardens, 2 gardens are the ones managed by other entities.
} 


\section{Allotment gardens in the planning documents of Poznan}

In SUiKZP of Poznan (2008), it is stated that allotment gardens constitute a major area of urban green space for special purposes, also providing an important addition to the wedgering system of urban green areas. In the same document, allotment gardens are not listed as an element of the green structure under the point, which refers to green areas, but are treated as agricultural production space, which is also consistent with the Act on the Protection of Agricultural and Forest Land from 1995. The document adopted in 2014, by contrast, includes allotment gardens as part of the green areas. Attention is also paid to the fundamental role of greenery in shaping the quality and condition of the environment as well as ensuring the maintenance and protection of biodiversity. Thus, this role is also ascribed to allotment gardens. In SUiKZP from the year 2014 in comparison to SUiKZP from 2008, the perception of the gardens, as areas of productive, recreational and social functions, has not change: The interest among the inhabitants, in allotment gardens, is not decreasing. It is not only the cultivation of vegetable crop, which is important to people with moderate incomes, but also a special form of relaxation and rest, especially for the elderly people.

In spite of the numerous, observed functions of allotment gardens in both documents, they are put into the category of 'temporary development'. Whereas, in terms of the physiognomy of the city, they are classified into the category of buildings, which disharmonize the urban landscape (especially the city center and downtown) by introducing spatial disorder and negatively affecting the perception of the city.

Classifying allotment gardens as areas of a temporary nature, which means transitional and unstable, leads to the conclusion that the way of using these gardens needs to be changed. However, in the SUiKZP from 2014, in the chapter on "Directions", it is implied that the current direction of land use should be maintained, with an allowance to convert allotment gardens into public greenery and sport areas. For example, in SUiKZP for Warsaw, it was allowed to transform allotment gardens into public areas of urban greenery or to be treated as a reserved terrain for the development of services, housing and transport functions (Giedych, Poniży 2013).

The study of the conditions and directions of spatial development, although a mandatory document drawn up by the municipality, is not an act of local law. It is, rather, a document of internal management whose records are only guidelines for future spatial development, which must be taken into account in the preparation of local plans.

Local plans, which are the acts of local laws, are the basis for spatial development. At the end of 2003, all the development plans adopted prior to 1995, lost their power. Moreover, large areas of Poznan remained without spatial regulations regarding the purpose as well as policies of land development, which could lead towards a disorderly development of settlements. Thus, the city area gradually began to be considered in the new urban plans of spatial development, which currently covers approx. 30\% of its area. Allotment garden have also been included in these plans.

There are still 58 of them $(60.4 \%)$ which, so far, have either not been covered by the local spatial development plans or the plans have not yet been

Table 1. Allotment Gardens in the local plans of spatial development of Poznan.

\begin{tabular}{|l|l|}
\hline \multicolumn{2}{|c|}{38 - allotment gardens covered by the local plans of spatial development } \\
\hline $\begin{array}{l}\text { 31 - allotment gardens totally covered by MPZP } \\
\text { including: }\end{array}$ & $\begin{array}{l}7 \text { - allotment gardens partially covered by MPZP } \\
\text { including: }\end{array}$ \\
\hline 20 gardens - maintaining their current function* & 3 gardens - maintaining their current function \\
\hline 2 gardens - with partial change in their function & 1 garden - with partial change in its function \\
\hline 7 gardens - change of their function & 3 gardens - change of their function \\
\hline 2 gardens - under planning; still non-existent & \\
\hline
\end{tabular}

* In the first decade of the 21st century, Allotment Garden "Ustronie" was still existing nearby the Municipal Stadium in Bułgarska Street - as a whole it was covered by the MPZP. The plan maintained function of the garden; however, it was finally liquidated by an administrative decision due to the expansion of the Stadium for EURO 2012. Source: Own work on the basis of data of Miejska Pracownia Urbanistyczna (Municipal Urbanism Workshop) in Poznan www.mpu.pl/plany.php (accessed 20.07.2014). 
adopted. The remaining 38 allotment gardens (less than 40\%) are within the range of the current local urban plans (Table 1). 31 gardens are entirely covered by the plans, while 7 of them are only partially covered. Among the allotment gardens, there are two more, still non-existent, which are covered by the plans as a whole. The city has provided a location for them in the northern part of Poznan, in the wedge of green.

Only 13 gardens, (13.5\%), are expected to have their function totally or partially modified. For most gardens, the changes concern traffic areas and are mainly related to the planned third frame of Poznan City communication as well as roads associated with sites for other purposes. Other changes include the adaptation of the areas of allotment gardens as service areas (education, commercial, religious), and residential - both high and low buildings. Only in the case of two allotment gardens, does the plans provide for the change from the current form of use into public greenery.

Although, the allotment gardens have been covered by local spatial development plans (which came into power in the years 20002013), in which there is a change in land use in place of the gardens, the vast majority of them
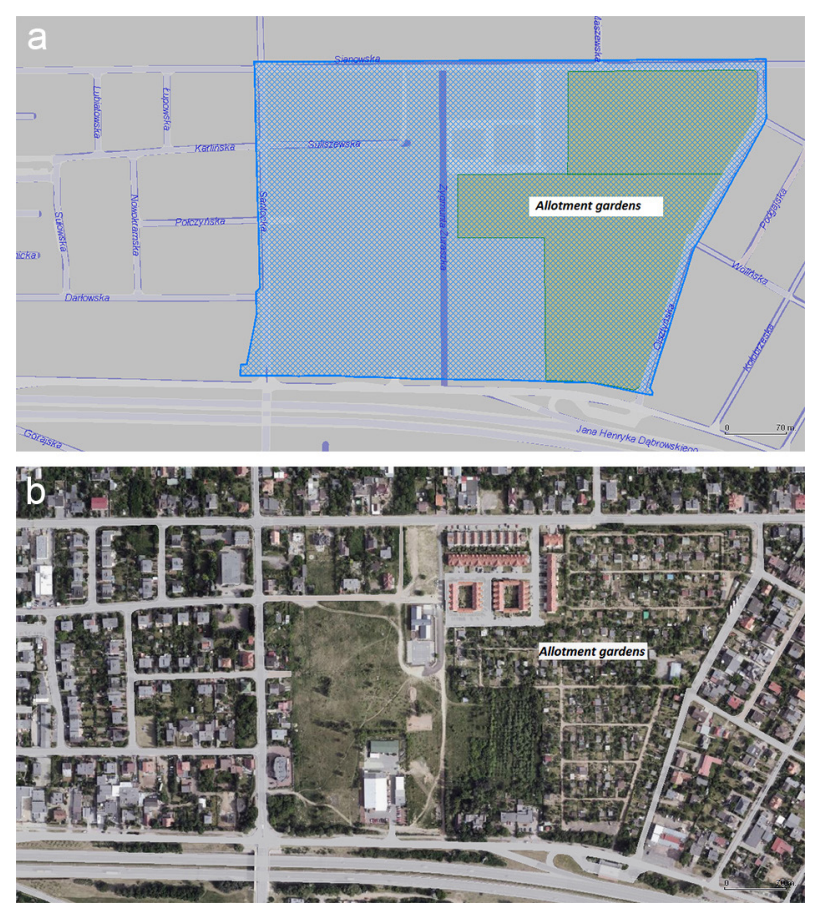

Fig. 1. Allotment gardens „Zjednoczeni” and „Olszynka" a) covered by MPZP adopted in 2003, and b) still existing on the satellite image from 2012. still exists as allotment gardens, for example, the "Zjednoczeni" and "Olszynka" Family Allotment Gardens (Fig. 1) for which the MPZP "Smochowice-Sianowska" (adopted in 2003) provides the change from the current form of land use into housing and service development.

Among the 13 allotments, there are two, which have been removed. However, due to the lack of implementation of the planned investment, some gardens are squatted, some abandoned by allotment gardeners, others undeveloped, neglected or degenerated into a substandard element within the landscape of the city. These include "J. Sobieski" and "O. Kopczyński" Allotment Gardens, located on the south side of Hetmańska Street covered by MPZP, and adopted in 2005.

Until now, because of the provisions of the MPZP, only in the case of two, out of the 13 mentioned allotment gardens, did we have something to do with a change of function.

In the case of the gardens that were not included in MPZP ( $60 \%$ of all the gardens in Poznan) after the year 1995, there were no significant changes observed in the way of their usage. The return of private property, requisitioned from their owners during the communist period (Family Allotment Garden "Sunflower", partly FAG "23rd February"), was the most important factor of the changes. Cases of some other allotment gardens are pending in court, under administrative proceedings, for the restitution of property. Some allotments, according to the information obtained from Poznan District Board of PZD, are mostly illegally occupied (FAG "Piotr Skarga", FAG "E. Orzeszkowa” or FAG “Z. Masłowski”). They have little to do with the idea of allotment gardening. Although other gardens still exist, one Allotment Garden, "EURO 2000", was created after the year 2000 in compensation for liquidated gardens - "Ustronie" and "O. Kopczyński".

\section{Conclusions}

The city authorities recognize the importance of allotment gardens within the system of green areas and observe their multi-functionality as indicated in the SUiKZP for Poznan, especially in the newer documents currently in force. At the same time, allotment gardens are looked upon as elements of disharmony in the city's landscape, 
and often treated as areas of reduced value. In spite of this, the guidelines for the preparation of local plans indicate the sustenance of existing functions, including the possibility of the conversion of the gardens into public greenery or parks. These recommendations should be considered for future plans.

So far, in the current local plans, when records relating to allotment gardens provide for changes in usage, they are mainly transformed into the elements of gray infrastructure and less often (only in 2 cases out of 13) into elements of green infrastructure.

The analysis of the local plans of spatial development, in view of allotment gardens, indicates that the spatial policy of Poznan authorities is conducive to maintaining allotment gardens within the spatial structure of the city. Admittedly, only a little more than $1 / 3$ of the total number of allotments was covered by MPZP, however, the records concerning them, in most cases, retain their function. What is more, MPZP secured the land for the establishment of new allotments. If such a trend were maintained for the next local plans to be enacted, more than $85 \%$ of the current gardens would remain on the map and new ones would still be created.

Although it would seem that the covering of the allotment gardens by MPZP is quite a solid "guarantee" for their continued existence, the example of Allotment Garden "Ustronie" in Poznan undermines this statement, because, despite the adopted plan and records to retain their function, allotments were liquidated based on administrative decision.

Despite not having the remaining allotment gardens covered by MPZP, the spontaneous or escalated conversion process of the gardens into investment areas was not observed, even after the year 2003. That was when the local, general plan of spatial development of the city of Poznan (adopted in 1994) ceased to be applicable and decisions on building requirements became the basis for spatial development, which was sometimes chaotic and difficult to control. Statutory provisions, along with MPZP, are still a factor that fosters and promotes the continued existence of allotment gardens in cities. According to the Act on Family Allotment Gardens from 2005, the liquidation of FAG can be carried out only with the consent of the Polish Association of Allotment Gardeners.
The new Law on Family Allotment Gardens from 2013, admittedly, allows the owner of the land (the Treasury or municipality) to liquidate the gardens located within his area, but is, at the same time, obliged to propose a replacement-land and financial compensation to users of these plots for the goods left in the liquidated gardens.

On the other hand, such a possibility can entail disappearing of allotment gardens from city centers, because they occupy very attractive land for development, highly desirable by investors. This may deprive the city centers of the valuable green areas, not only from inhabitants recreation or social cohesion point of view, but ecology as well, since as Borysiak et.al. (2016) noted allotment gardens should be considered as biodiversity hotspots for native species within urban green infrastructure and according to Matthies et al. (2015) urban green spaces larger than 6 ha (thus allotment gardens as well) are characterized by particular vascular plant species richness and because of that they should be priority protected.

\section{Acknowledgement}

This paper was prepared within the framework of the activities of Working Group 1: Policy and Urban Development, COST Action TU 1201: Urban Allotment Gardens in European Cities Future Challenges and Lessons Learned.

\section{References}

Act of 3 February 1995 on agricultural and forested land protection. Dz. U. 1995 No.16 item 78.

Borysiak J., Mizgajski A., Speak A., 2016. Floral biodiversity of allotment gardens and its contribution to urban green infrastructure. Urban Ecosystems 2016. DOI 10.1007/ s11252-016-0595-4

Breuste J., 2010. Allotment gardens as part of urban green infrastructure: actual trends and perspectives in Central Europe. In: Müller N., Werner P., Kelcey J., (eds), Urban biodiversity and design - Implementing the convention on biological diversity in towns and cities. Wiley-Blackwell, Oxford: $463-475$.

Central Statistical Office of Poland, Statistical Office in Poznan. Voivodship cities, basic statistical data. Warszawa 2009. Online: stat.gov.pl/cps/rde/xbcr/gus/OZ miasta_wojewodzkie_nr_17.pdf (accessed 28 December 2014).

Drilling M., Giedych R., Poniży L., 2016. The idea of allotment gardens and the role of spatial and urban planning. In: Bell S., Fox-Camper R., Keshavarz N., Benson M., Caputo S., Noori S., Voigt A., (eds), Urban Allotment Gardens in Europe. Routledge, London and New York: 35-61. 
Family Allotment Gardens Act of 13 December 2013. Dz. U. 2014 item 40.

Family Allotment Gardens Act of 8 July 2005 Dz.U. 2005 No. 169 item 1419.

Giedych R., Poniży L., 2013. Ogrody działkowe jako przedmiot polityki przestrzennej i ekologicznej miast na przykładzie Warszawy i Poznania (Allotment gardens as a subject of spatial and environmental policies of a city. Poznan and Warsaw case study). In: Kosmala M. (ed.), Ogrody działkowe w miastach - bariera czy wartość? PZITS Oddział Toruń: 23-34.

Gill S. E., Handley J. F., Ennos A. R., Pauleit S., 2007. Adapting cities to climate change: the role of the green infrastructure. In: Built Environment 33(1): 115-133.

Hostetler M., Allen W., Meurk C., 2011. Conserving urban biodiversity? Creating green infrastructure is only the first step. Landscape and Urban Planning 100 (2011): 369-371.

Jim C.Y., Chen W.Y., 2006. Recreation-amenity use and contingent valuation of urban green spaces in Guanzhou, China. Landscape and Urban Planning 75: 81-96.

Kronenberg J., Bergier T., Lisicki P., 2013. Usługi ekosystemów w praktyce a ogrody działkowe ( Ecosystem services in practice and allotment gardens) . In: Kosmala M. (ed). Ogrody działkowe w miastach - bariera czy wartość? PZITS Oddział Toruń, Toruń: 158-168.

Langemeyer J., Latkowska M.J., Gomez-Baggethun E.N., 2016. Ecosystem services from urban gardens. Bell S., Fox-Camper R., Keshavarz N., Benson M., Caputo S., Noori S., Voigt A., (eds), Urban Allotment Gardens in Europe. Routledge, London and New York:115-141.

Local Plans of Spatial Development of Poznan, Municipal Urbanism Workshop (Miejscowe plany zagospodarowania przestrzennego - MPZP, Miejska Pracownia Urbanistyczna Poznan). Online: www.mpu.pl/plany.php (accessed 18 July 2014).

Malinowska E., Szumacher I., 2008. Rola ogrodów działkowych w krajobrazie lewobrzeżnej Warszawy. In: Bródka S. (ed.). Problemy Ekologii Krajobrazu 22: 139-150.

Matthies SA., Rüter S., Prasse R., Schaarschmidt F., 2015. Factors driving the vascular plant species richness in urban green space: using a multivariable approach. Landscape and Urban Planning 134:177-187.

Müller N., Werner P., Kelcey J. G., 2010. Urban biodiversity and design. Wiley-Blackwell. Singapore.

Municipal map ZGiKM GEOPOZ. Online: www.city.poznan. pl/mapa_geopoz/poznan_internet.php (accessed 2 July 2014).

Pauleit S., Duhme F., 2000. Assessing the environmental performance of land cover types for urban planning. Landscape and Urban Planning 52: 1-20.

Pawlak J., 2013. Ogrody działkowe w polityce przestrzennej Warszawy (Allotment gardens in the spatial policy of Warsaw). In: Kosmala M. (ed.), Ogrody działkowe w miastach - bariera czy wartość? PZITS Oddział Toruń, Torun: 35-44.

Regulation of the Minister of Infrastructure of 26 August 2003 , on the required scope of the project of the local plan of spatial development. Dz.U. 2003 No. 164 item 1587.

Resolution of the City Council of Poznan No. LXXII/1137/ VI/2014 of 23 September 2014 on Municipal Study of Spatial Preconditions and Directions of Development of the City of Poznan.

Resolution of the City Council of Poznan No. XXXI/299/V/2008 of 18 January 2008 on Amendments to Municipal Study of Spatial Preconditions and Directions of Development of the City of Poznan.

Sandström U.G., 2002. Green Infrastructure Planning in Urban, Sweden. Planning Practice \& Research 17(4): 373-385.

Tratalos J. Fuller R.A., Warren P.H., Davies R.G., Gaston K. J., 2007. Urban form, biodiversity potential and ecosystem services. Landscape and Urban Planning 83(4): 308-317.

Tyrväinen L., Pauleit S., Seeland K., de Vries S., 2005. Benefits and Uses of Urban Forests and Trees. (Chapter 4) In: Konijnendijk C.C., Nilsson K., Randrup Th.B., Schipperijn J. (eds), Urban Forests and Trees. Springer, Heidelberg: 81-114.

Wise S., 2008. Green Infrastructure Rising: Best practices in stormwater management. Planning, August/September 2008. Online: www.kcmo.org/idc/groups/water/ documents/waterservices/greeninferstruc.pdf (accessed 15 February 2013). 